Indonesian Journal of Cardiology

Indonesian J Cardiol 201 7:38:2 I 8-25

pISSN: 0I 26-3773 / elSSN: 2620-4762

\title{
Pulmonary Atresia with Intact Ventricular Septum in a Neonate
}

\author{
Emir Yonas', Raymond Pranata ${ }^{2}$, Nuvi Nusarintowati ${ }^{3}$,
}

'Faculty of Medicine, YARSI University, Jakarta, Indonesia ${ }^{2}$ Faculty of Medicine, Universitas Pelita Harapan, Tangerang, Indonesia ${ }^{3}$ Pediatric Cardiology division, University Of Indonesia, Jakarta, Indonesia
Introduction: Pulmonary atresia with an intact ventricular septum is a condition that is characterized by a complete obstruction to right ventricular outflow with varying degrees of right ventricular and tricuspid valve hypoplasia. This condition is uniformly fatal if untreated. In this case report, we present a case of a neonate with a pulmonary atresia with intact ventricular septum

Case Presentation: A 2 days-old female Indonesian newborn was referred to our facility. The newborn was delivered from a G4P3A0 mother with a gestational age of 39 weeks (term delivery). Chest $\mathrm{x}$-ray done at the referring facility is significant for a seemingly right heart hypertrophy, casting a "boot-shaped" appearance of the right heart border. Laboratory results done at the referring facility is significant for a neutrophilia of $82 \%$ and lymphocytopenia of $13 \%$ An episode of hypoglycemia was reported on referring facility with a blood sugar level of $50 \mathrm{mg} / \mathrm{dl}$. Multiple episodes of cyanosis were reported at referring facility, CPAP was administered but the improvement was limited. Pulse oximetry averaged between $72-80 \%$ at the referring facility. Physical examination shows an actively moving neonate, with a strong cry. Perioral cyanosis was seen. Vital signs were as follows; heart rate $128 \times$ / minute, temperature $370 \mathrm{C}$, respiratory rate $54 \times$ / minute, pulse oximetry $74 \%$, capillary refill time $<3$ seconds. The rest of the physical examination was within normal limits. Laboratory result on admission at our facility is significant for low hematocrit, low erythrocyte count, leukopenia with neutrophilia and thrombocytopenia. Patient was admitted to NICU and given CPAP. Echocardiography 2 days upon arrival at our facility reveals a patent ductus arteriosus with the pressure of $4-5 \mathrm{mmHg}$ and diameter of $0.3 \mathrm{~cm}$, no forward flow from the right ventricle to the pulmonary artery, doppler mode demonstrated pulmonary artery filling from ductus arteriosus. The rest of the findings were within normal limits.

Conclusion: Pulmonary atresia with an intact ventricular septum is a condition that relies on the patent ductus arteriosus for pulmonary blood supply, the patency of it is of paramount importance.

(Indonesian J Cardiol. 2017;38:2 I8-25)

Keywords: Pulmonary Atresia, Patent Ductus Arteriosus, congenital heart disease, hypoxic spells, cyanosis 


\title{
Atresia Pulmonal dengan Septum Ventrikel Intak pada Neonatus
}

\author{
Emir Yonas ${ }^{1}$, Raymond Pranata ${ }^{2}$, Nuvi Nusarintowati ${ }^{3}$,
}

PENDAHULUAN: Atresia arteri pulmonalis dengan septum ventrikel yang utuh merupakan kondisi yang dikarakterisasikan dengan sumbatan total pada right ventricular outflow dengan berat hipoplasia ventrikel kanan dan trikuspid kanan yang beratnya bervariasi. Pada umumnya kondisi tersebut fatal apabila tidak ditangani. Pada laporan kasus ini, kami melaporkan suatu kasus neonates dengan atresia arteri pulmonalis dengan septum ventrikel yang utuh.

PRESENTASI KASUS: Neonatus perempuan berumur 2 hari dirujuk ke rumah sakit kami. Bayi dilahirkan dari G4P3A0 usia kehamilan 39 minggu. Ronsen thoraks yang dilakukan oleh fasilitas kesehatan yang merujuk memperlihatkan hipertrofi jantung kanan serta bentuk "bootshaped” pada batas jantung kanan. Hasil laboratorium pada fasilitas kesehatan tersebut menunjukan neutrofilia dan limfositopenia. Terdapat juga riwayat hipoglikemi. Episode sianosis berulang terjadi pada fasilitas kesehatan yang merujuk. Pemasangan CPAP kurang membuahkan hasil dengan saturasi O2 72-80\% ketika tiba pada rumah sakit kami. Pemeriksaan fisik menunjukan tangis kuat dan gerak aktif dengan sianosis perioral. Detak jantung $128 \mathrm{kali} /$ menit, suhu $37 \mathrm{oC}$, laju naas $54 \mathrm{kali} /$ menit, oksimetri nadi $74 \%$ dan waktu isi kapiler $<3$ detik. Pemeriksaan laboratorium saat pasien dating menunjukan hematocrit, hitung eritrosit, leukosit dan thrombosit yang rendah. Pasien dirawat di NICU dan diberikan CPAP. Ekokardiografi 2 hari kemudian menunjukan duktus arteriosus patent dengan tekanan $4-5 \mathrm{mmHg}$ dan diameter $0.3 \mathrm{~cm}$, tidak ada aliran maju dari ventrikel kanan kepada arteri pulmonalis, mode Doppler menunjukan pengisian arteri pulmonalis dari duktus arteriosus. Pemeriksaan lainnya dalam batas normal.

KESIMPULAN: Atresia arteri pulmonalis dengan septum ventrikel yang utuh merupakan suatu kondisi dimana aliran darah menuju paru bergantung pada duktus arteriosus yang paten sehingga patensi daripada duktus tersebut sangatlah penting.

(Indonesian J Cardiol. 2017;38:218-25)

Kata Kunci: Atresia pulmonalis, duktus arteriosus paten, penyakit jantung bawaan, periode hipoksik, sianosis

'Fakultas Kedokteran, Universitas YARSI, Jakarta, Indonesia, ${ }^{2}$ Fakultas Kedokteran, Universitas Pelita Harapan, Tangerang, Indonesia, ${ }^{3}$ Divisi Kardiologi Pediatrik, Universitas Indonesia, Jakarta, Indonesia

\section{Correspondence:}

Dr.Emir Yonas, Facult of Medicine, YARSI University, Jakarta, Indonesia. E-mail: e yonas@windowslive.com

\section{Introduction}

Pulmonary atresia with an intact ventricular septum is a condition that is characterized by a complete obstruction to right ventricular outflow with varying degrees of right ventricular and tricuspid valve hypoplasia. As a result of these defects, blood is thus unable to flow from the right ventricle to the pulmonary artery and lungs, and an alternative source of blood flow is then required for survival. This condition is uniformly fatal if untreated. 
In this case report, we present a case of a neonate with a pulmonary atresia with intact ventricular septum

\section{Case Presentation}

A female Indonesian newborn was referred to our facility. Due to suspicion of cyanotic heart disease. The newborn was delivered 2 days prior to referral to our facility via cesarean section. The newborn was delivered from a G4P3A0 mother with a gestational age of 39 weeks (term delivery). Weight on delivery was 2500 grams, body length 47 centimeters, with an Apgar score at 1 and 5 minutes of 7 and 9 respectively. She was referred to our facility aged 48 hours. An inquiry of the gestational history reveals a term, appropriate for gestational age fetus. Maternal age at current pregnancy was 38 years old. The mother had 1 vaginal delivery and 2 cesarean section previously. The mother denied any history of sickness during pregnancy. Patient's parents denied any history of illnesses of the heart and lungs in the family. Chest $\mathrm{x}$-ray done at the referring facility is significant for a seemingly right heart hypertrophy, casting a "boot-shaped" appearance of the right heart border. Assessment of lung vasculature on CXR reveals an oligemic lung.

The neonate was given intramuscular vitamin $\mathrm{K}$, ophthalmic antibiotic drops, normal saline intravenously and cefotaxime (2x $125 \mathrm{mg}, 4$ doses in total) at referring facility.

Laboratory results done at the referring facility is significant for a neutrophilia of $82 \%$ (normal range for individuals $<1$ years old: 17-60\%) and lympho-

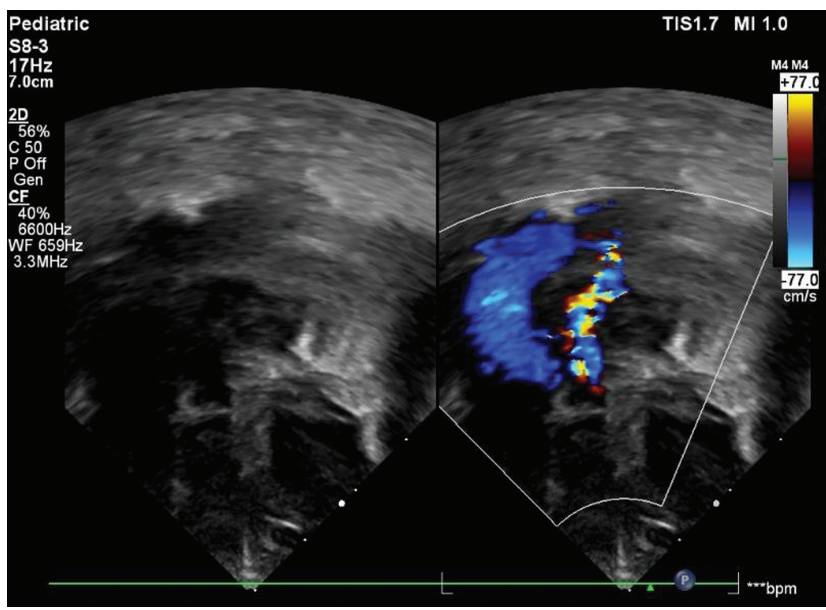

Figure 1. Patient's echocardiography showing patent ductus arteriosus filling from the aorta cytopenia of $13 \%$ (normal range for individuals $<1$ years old: $20-70 \%$ ), the rest of laboratory values are within normal limits.

An episode of hypoglycemia was reported on referring facility with a blood sugar level of $50 \mathrm{mg} /$ $\mathrm{dl}$, subsequently, the neonate was given dextrose $10 \%$ with normal saline. No further episodes are reported. Multiple episodes of cyanosis were reported at referring facility, CPAP was administered but the improvement was limited. Pulse oximetry averaged between $72-80 \%$ at the referring facility.

Upon arrival at our institution, a physical examination shows an actively moving neonate, with a strong cry. Perioral cyanosis was seen. Vital signs were as follows; heart rate $128 \times$ / minute, temperature $37 \mathrm{oC}$, respiratory rate $54 \mathrm{x} /$ minute, pulse oximetry $74 \%$, capillary refill time $<3$ seconds. Cardiac auscultation reveals single and decreased second heart sound, with no other murmur audible. The rest of the physical examination was within normal limits.

Laboratory result on admission at our facility is significant for low hematocrit of $37 \%$ (normal range 42-60\%), low erythrocyte count of $3.8 \mathrm{mil} / \mathrm{microliter}$ (normal range 3.9-5.5 $\mathrm{mil} / \mathrm{microliter}$ ), leukopenia with WBC count of 3190 (normal range 9000-30,000 / microliter), thrombocytopenia with count of 142000 / microliter (normal range 150,000-400,000 / microliter). Differential counting of white blood cell showed neutrophilia of 73\% (normal range 50-70\%).

A suspicion of PAIVS was established by physical examination and chest $\mathrm{X}$ ray, the neonate was then admitted to our neonatal intensive care unit. Continu-

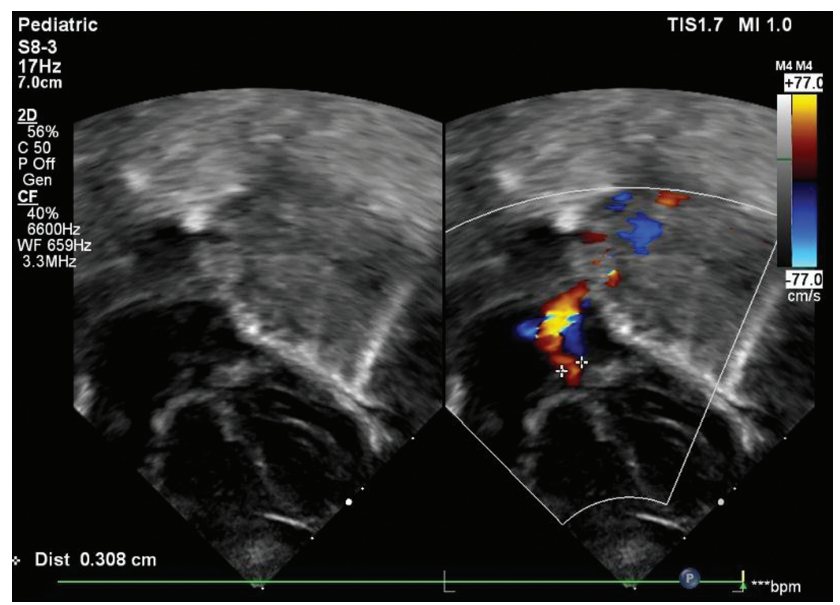

Figure 2. Patient's echocardiography showing patent ductus arteriosus width 
ous positive airway pressure was administered with a fraction of inspired oxygen of $30 \%$ and pressure of 5 $\mathrm{cmH} 2 \mathrm{O}$.

Echocardiography 2 days upon arrival at our facility reveals a patent ductus arteriosus with the pressure of $4-5 \mathrm{mmHg}$ and diameter of $0.3 \mathrm{~cm}$, no forward flow from the right ventricle to the pulmonary artery, doppler mode demonstrated pulmonary artery filling from ductus arteriosus. Monopartite right ventricular morphology was seen. Pulmonal valve morphology was unable to be visualized. The rest of the findings were within normal limits. As per consultation with the pediatric cardiologist, it is advised the patient be administered prostaglandin E1 infusion at the rate of 10-30 nanogram $/ \mathrm{KgBW} /$ minute intravenously in the event of desaturation.

\section{Discussion}

Pulmonary Atresia with intact ventricular septum (PAIVS) is a rare congenital defect that consists of atresia of the pulmonary valve resulting in an absent connection between the right ventricular outflow tract and the pulmonary arteries, and an intact ventricular septum that allows no connection between the right and left ventricles.

It is to be considered that PAIVS is a distinct defect compared to pulmonary atresia in ventricular septal defect and Ebstein anomaly. It is different that PAIVS features developmental abnormalities of the right ventricle with the tricuspid valve that is upstream of the pulmonary outflow. The pulmonary arteries in PAIVS are small, but the architecture and branching are normal. While in pulmonary atresia in ventricular septal defect, the right ventricle is normally-formed and the relation between the tricuspid valve and the pulmonary artery is inverted in that downstream abnormalities of the pulmonary arteries are present, compared with upstream abnormalities of PAIVS

The reported incidence of this condition is based on registries and population-based studies of children born with congenital heart disease are approximately four to eight per 100,000 live births. PAIVS itself accounts for 1 to 3 percent of all congenital cardiac defects in children regardless of gender. ${ }^{1,2}$

The pathogenesis of this condition is unknown. Compared to other cardiac lesions, identifiable genetic syndromes and other cardiac malformations are less common in PAIVS. It has been proposed that
PAIVS is an acquired lesion due to perturbation in fetal blood flow, based on reports of serial ultrasound studies showing the development of pulmonary atresia in fetuses. This theory has led to fetal interventions including in utero dilation of the pulmonary valve to promote blood flow through the right ventricular outflow tract. $3,4,5$

In some other cases, it has been proposed that viral infection or inflammatory conditions in midterm gestation creates an atretic pulmonary valve and the subsequent abnormalities of fetal blood flow which result in the occurrence of PAIVS. However, as per current observations, no relationship has been established between PAIVS and maternal rubella, despite the reported associations. ${ }^{6,7}$

While on the other hand, pulmonary atresia with a ventricular septal defect, is thought to be an early gestational developmental lesion resulting from an abnormality in primary morphogenesis of the heart.

PAIVS consists of a wide variety of anatomical cardiac defects that are associated with the primary lesion of pulmonary atresia.

In patients with PAIVS, the underlying abnormality of the pulmonary atresia is either valvular or muscular in origin. Most cases are caused by an atretic pulmonary valve with a small valve annulus and identifiable but fused valve leaflets which form a thin intact membrane that causes right ventricular outflow tract obstruction. In these patients, the RV and infundibulum shaped muscular structure that forms the right ventricular outflow tract below the pulmonary valve are usually well developed..$^{8,9}$

In approximately 20 to 25 percent of patients, there is an obliteration of the muscular infundibulum resulting in muscular pulmonary atresia. This finding is usually associated with severe right ventricular hypoplasia, increased risk, and severity of coronary artery abnormalities and poor outcome. , $^{8,10,11}$

A right ventricular defect is associated with the pulmonic valve abnormality. A great variation of the morphology of the right ventricle can be observed. It ranges from a severely hypoplastic small cavity with marked muscular hypertrophy to a large, dilated, thinwalled chamber. This variation is due to the degree of intracavitary muscular overgrowth. Normally the right ventricle is composed of three parts; an inlet, a body and an outlet.

Majority of patients will have a well formed tripartite right ventricle ( 59 to 83 percent), while the rest will have a bipartite right ventricle which is caused by 
the overgrowth of apical trabecular tissues in a small ventricle which consist of an inlet, a body, but no outlet (15 to 34 percent), small number of patient will have unipartite right ventricle due to overgrowth of both infundibular and apical trabecular tissues, resulting in hypoplastic right ventricle with only a detectable inlet ( 2 to 8 percent).$^{8,10}$

The size of the tricuspid valve is highly variable and the valve is often and dysplastic with stenosis and or regurgitation. However, it is to be noted that the size of the tricuspid annulus correlates with the size and morphology of the right ventricle and it will be used as a consideration in deciding. the choice of intervention, in the terms of biventricular repair versus an univentricular palliation. ${ }^{12}$

Patients with PAIVS will have abnormalities in the coronary arteries. Abnormal connections between the right ventricle and coronary arteries are commonly found, this is thought to be caused by the high pressure in the dysplastic right ventricular cavity. Patients with a severely hypoplastic tricuspid valve and a small hypertensive right ventricle are more likely to have fistulae. Coronary stenoses and interruptions will occur due to fistula formations. ${ }^{13,14,15}$

Pulmonary circulation in PAIVS is usually supported by normal left-sided patent ductus arteriosus, as what is found in this patient, which connects to confluent pulmonary arteries with a normal branching pattern from the main pulmonary trunk. It is rare for patients with PA IVS to have abnormal development of pulmonary arteries. ${ }^{16}$

Although gross anatomic abnormalities of the pulmonary vasculature in PAIVS is uncommon, one histologic study shows a significant medial and intimal abnormalities, possibly related to the variation of pressure due to ductal dependent pulmonary blood flow compared to normal individuals. ${ }^{17}$

Other less common defects can occur in PAIVS, it usually affects the left ventricle, aortic valve, and right atrium and thus are not pathognomonic for this condition

In PAIVS, pulmonary atresia causes right ventricular outflow obstruction. Due to the normal ventricular septum, there are only two ways left for blood to exit the right ventricle: (1) via tricuspid regurgitation back into the right atrium and (2) through the connections with the coronary artery circulation with the right ventricle.

The pressure of right ventricle is dependent on the extent of right ventricular outflow. In cases with limited tricuspid regurgitation and coronary circulation flow, the pressure of the right ventricle can exceed systemic levels, reaching as high as $200 \mathrm{mmHg}$ in some cases. While on the other hand, the right ventricular pressure can be normal in patients with tricuspid regurgitation.

The patency of ductus arteriosus is of paramount importance in PAIVS, it is crucial that the ductus kept open even after birth, as it is the only source of pulmonary blood supply.

Cyanosis is present in neonates with PAIVS due to an obligate right to left shunt at the atrial level. Severe respiratory distress in an uncommon finding and the occurrence differentiate these patients from those with the pulmonary cause of cyanosis. However, mild tachypnea and hyperpnea are common findings. ${ }^{10}$

An untreated PAIVS is an almost uniformly fatal disease. Pulmonary atresia with an intact ventricular septum is a ductal dependent lesion, closure of the patent ductus arteriosus generally results in rapid clinical deterioration and life-threatening consequences, which includes severe metabolic acidosis, hypoxemia, seizures, cardiogenic shock, cardiac arrest, and death. ${ }^{18}$

In addition to cyanosis, other physical findings may include a single second heart sound due to a single semilunar valve, systolic murmur due to tricuspid regurgitation, and albeit less commonly, a continuous machinery type murmur due to the patent ductus arteriosus. Pulse oximetry will reveal desaturation that consistent with physical findings of cyanosis. It is to be noted that the systemic oxygen saturation depends on the amount of left to right shunt from the aorta to the pulmonary arteries via the PDA.

Echocardiography is essential in confirming the diagnosis of PAIVS, it also provides information regarding the size and function of the right ventricle. Echocardiography is also capable to evaluate the intracardiac mixing of blood and the pulmonary blood flow. The evaluation that can be done using echocardiography includes the following; (1) assessment of size and function of right ventricle, (2) measurement of tricuspid valve size and function, (3) assessment of intracardiac mixing and pulmonary blood flow, (4) assessment of left ventricular function, aortic valve, and left ventricular outflow tract.

Further evaluation regarding the patency and possible abnormalities of the coronary arteries can be done through a cardiac catheterization.

Initial stabilization of PAIVS emphasizes on ensuring adequate systemic oxygenation, while also stabilizing the cardiac and pulmonary function. The goal of the initial approach is to stabilize and optimize the neonate's 
condition so that further repairs can be attempted. Pharmacological therapy is directed towards providing sufficient intracardiac mixing of blood by ensuring the patency of the ductus arteriosus with a prostaglandin E1 infusion. It is to be noted that the cardiac output in this condition is dependent on blood shunting from the right to the left atrium. General cardiorespiratory support for infants that suffers from either respiratory compromise, poor perfusion, acidosis, and or hypotension will also be included in the initial management of PAIVS. Measures to counteract these derangements will include respiratory support with either supplemental oxygen or mechanical ventilation, inotropic agents, and correction of metabolic derangements. ${ }^{8}$

There are several options for corrective surgical repair or palliation for patients with PAIVS, the choice of approach will best be determined by pediatric cardiologists and cardiothoracic surgeons. These approaches can include; $;^{19,20}$

- A biventricular repair, in which separation of pulmonary and systemic circulations with two pumping ventricles will be done

- Univentricular palliation, which will separate the pulmonary and systemic circulations with a single pumping ventricle

- Hybrid/1.5 ventricle repair, which separates the pulmonary and systemic circulations with two pumping ventricles, with the exception that the right ventricle is not totally supporting the pulmonary circulation by itself. In this approach, Glenn procedure will be performed which will then provides a direct source of pulmonary blood flow from the superior vena cava, while the inferior vena cava is channeled to the right ventricle and the reconstructed pulmonary valve. At a later time when right ventricular growth is sufficient to support the pulmonary circulation, catheter-based closure of the patent foramen ovale or atrial septal defect can be attempted.

- Primary cardiac transplantation

The management of PAIVS is a combined medical and surgical effort, with the burden of decision making shared on both disciplines and on anatomical and physiological data of the lesion, to assess the feasibility of biventricular repair. Several methods are available to help provide morphologic data that will help decision making in the choice of management:

- Echocardiography is done to measure the size and morphology of the right ventricle and to assess the tricuspid valve is possible

- Cardiac catheterization is performed on almost all patients with PAIVS, the purpose of this is to assess the existence of right ventricle-dependent coronary circulation (RVDCC), which will impose as a barrier to proceed to biventricular repair, patients with RVDCC will typically undergo palliative approaches.

Furthermore, in the setting of marked cyanosis not responding to pharmacologic agents, patients can undergo balloon valvuloplasty of the pulmonary valves, patients with pulmonary atresia are candidates for balloon valvuloplasty, provided that the morphology of obstruction is membranous, the right ventricular size is adequate for repair, and there's no RVDCC. However, as our patient exhibited improvement after administration of prostaglandin, this is not necessary.

This patient experienced multiple episodes of desaturations, in which continuous positive airway pressure ventilation was implemented, albeit the limited improvement, this is caused by a right to left shunting that occurs as the right ventricular outflow tract is obstructed. No amount of oxygenation can correct the subnormal levels of oxygen in this patient's blood due to it being caused by the intracardiac mixing of oxygenated and deoxygenated blood. If one were to do blood gas analysis on this patient and count the alveolar-arterial oxygen gradient of this patient, it will show results exceeding 15 point due to it being caused by shunting. Prostaglandin E1 was administered in the setting of desaturation, and the patient improved shortly afterward.

From echocardiography result of this patient, it is apparent that the blood flow to the pulmonary vasculature originated from the aorta via the ductus arteriosus, as demonstrated by the Doppler mode echocardiography result of this patient. Echocardiography also shows an atrial septal defect, which acts as a conduit of blood from the right side of the heart to the left side of the heart.

The implementation of ventilation support in cases of PAIVS is not without its risks, it is a wellestablished fact that at birth, the rise in systemic arterial oxygen tension, and a decrease in circulating levels of prostaglandin E2 are the main factors that induce the constriction and subsequent obliteration of ductus arteriosus. The administration of supplemental oxygen will further hasten the closure of ductus arteriosus in these cases, which will bring catastrophic consequences and rapid clinical dete- 
rioration as the pulmonary blood flow is obliterated. In the face of these considerations, it is dangerous to continue oxygen supplementation without establishing the echocardiographic diagnosis in cases of suspected PAIVS.

As the ductus arteriosus remains a critical anatomic part prior to corrective surgery, it is highly important that it kept open, in this case, we advised the administration of prostaglandin E1 infusion at the rate of $10-30$ nanogram $/ \mathrm{KgBW} /$ minute intravenously in the event of desaturation, in order to maintain patency of ductus arteriosus.

The authors acknowledged that there are limitations to this case report, such as the use of CPAP in this patient, which has limited benefit and has been ceased after consultation with the pediatric cardiologist. We are also unable to determine the existence of RVDCC and $\mathrm{z}$ score calculation at the time of this case report due to the patient not undergoing catheterization at our facility and being referred to another tertiary care center to undergo further management.

\section{Conclusion}

Pulmonary atresia with an intact ventricular septum is a condition that relies on the patent ductus arteriosus for pulmonary blood supply, the patency of it is of paramount importance. Therefore, it is dangerous to continue oxygen supplementation without a proper diagnosis as it can cause ductal closure and rapid deterioration of the patient.

\section{Abbreviations}

CPAP: Continous Positive Airway Pressure

NICU:Neonatal Intensive Care Unit

PDA: Patent Ductus Arteriosus

PAIVS: Pulmonary Atresia with Intact Ventricular Septum

RVDCC: Right ventricle dependent coronary circulation

\section{Declarations}

\section{Ethics Approval and consent to par- ticipate}

Not Applicable

\section{Consent for publication}

Written informed consent was obtained from the patient's legal guardian(s) for publication of this case report and any accompanying images. A copy of the written consent is available for review by the Editorin-Chief of this journal

\section{Availability of data and material}

The datasets supporting the conclusions of this article are included in the article

\section{Competing interests}

The authors declare that they have no competing interests

\section{Funding}

No source of funding

\section{Authors' contributions}

$\mathrm{NN}$ admitted, evaluate and treat the patient. EY and $\mathrm{RP}$ also planned and drafted the manuscript. EY and RP performed extensive research on the topic. NN supervised and gave expert advice regarding the manuscript. All authors read and approved the final manuscript

\section{Acknowledgements}

Not Applicable

\section{References}

1. Report of the New England Regional Infant Cardiac Program. Pediatrics 1980; 65:375.

2. Samánek M, Vorísková M. Congenital heart disease among 815,569 children born between 1980 and 1990 and their 15-year survival: a prospective Bohemia survival study. Pediatr Cardiol 1999; 20:411.

3. Rudolph AM. Congenital diseases of the heart : clinical-physiological considerations, Wiley-Blackwell, Hoboken, NJ 2009.

4. Gardiner HM. Progression of fetal heart disease and rationale for fetal intracardiac interventions. Semin Fetal Neonatal Med 2005; 10:578.

5. Kutsche LM, Van Mierop LH. Pulmonary atresia with and without ventricular septal defect: a different etiology and 
pathogenesis for the atresia in the 2 types? Am J Cardiol 1983; 51:932.

6. Jenkins KJ, Correa A, Feinstein JA, et al. Noninherited risk factors and congenital cardiovascular defects: current knowledge: a scientific statement from the American Heart Association Council on Cardiovascular Disease in the Young: endorsed by the American Academy of Pediatrics. Circulation 2007; 115:2995.

7. Botto LD, Lynberg MC, Erickson JD. Congenital heart defects, maternal febrile illness, and multivitamin use: a populationbased study. Epidemiology 2001; 12:485.

8. Daubeney PE, Delany DJ, Anderson RH, et al. Pulmonary atresia with intact ventricular septum: range of morphology in a population-based study. J Am Coll Cardiol 2002; 39:1670.

9. Braunlin EA, Formanek AG, Moller JH, Edwards JE. Angiopathological appearances of pulmonary valve in pulmonary atresia with intact ventricular septum. Interpretation of nature of right ventricle from pulmonary angiography. Br Heart J 1982; 47:281.

10. Dyamenahalli U, McCrindle BW, McDonald C, et al. Pulmonary atresia with intact ventricular septum: management of, and outcomes for, a cohort of 210 consecutive patients. Cardiol Young 2004; 14:299.

11. Kipps AK, Powell AJ, Levine JC. Muscular infundibular atresia is associated with coronary ostial atresia in pulmonary atresia with intact ventricular septum. Congenit Heart Dis 2011; 6:444.

12. Hanley FL, Sade RM, Blackstone EH, et al. Outcomes in neonatal pulmonary atresia with intact ventricular septum. A multiinstitutional study. J Thorac Cardiovasc Surg 1993; 105:406.
13. Calder AL, Co EE, Sage MD. Coronary arterial abnormalities in pulmonary atresia with intact ventricular septum. Am J Cardiol 1987; 59:436.

14. Freedom RM, Anderson RH, Perrin D. The significance of ventriculo-coronary arterial connections in the setting of pulmonary atresia with an intact ventricular septum. Cardiol Young 2005; 15:447.

15. Calder AL, Peebles CR, Occleshaw CJ. The prevalence of coronary arterial abnormalities in pulmonary atresia with intact ventricular septum and their influence on surgical results. Cardiol Young 2007; 17:387.

16. Mainwaring RD, Sheikh AY, Punn R, et al. Surgical outcomes for patients with pulmonary atresia/major aortopulmonary collaterals and Alagille syndrome. Eur J Cardiothorac Surg 2012; 42:235.

17. Tanaka T, Yamaki S, Kakizawa H. Histologic study of the small pulmonary arteries in 38 patients with pulmonary atresia and intact ventricular septum. Jpn Circ J 1996; 60:293.

18. McArthur JD, Munsi SC, Sukumar IP, Cherian G. Pulmonary valve atresia with intact ventricular septum. Report of a case with long survival and pulmonary blood supply from an anomalous coronary artery. Circulation 1971; 44:740.

19. Odim J, Laks H, Tung T. Risk factors for early death and reoperation following biventricular repair of pulmonary atresia with intact ventricular septum. Eur J Cardiothorac Surg 2006; 29:659.

20. Li S, Chen W, Zhang Y, et al. Hybrid therapy for pulmonary atresia with intact ventricular septum. Ann Thorac Surg 2011; $91: 1467$. 